\title{
Honey: Another Alternative in the Fight against Antibiotic-Resistant Bacteria?
}

\author{
Patricia Combarros-Fuertes ${ }^{1}{ }^{\circledR}$, José M. Fresno ${ }^{1}\left(\mathbb{D}\right.$, Maria Manuela Estevinho ${ }^{2}$, \\ Mário Sousa-Pimenta ${ }^{3}$, M. Eugenia Tornadijo ${ }^{1}$ and Leticia M. Estevinho ${ }^{4, *}$ \\ 1 Department of Food Hygiene and Technology, Faculty of Veterinary Science, University of León, \\ Campus de Vegazana, 24071 León, Spain; pcomf@unileon.es (P.C.-F.); jmfreb@unileon.es (J.M.F.); \\ metorr@unileon.es (M.E.T.) \\ 2 Department of Biomedicine, Unit of Pharmacology and Therapeutics, Faculty of Medicine, \\ University of Porto, 4200-319 Porto, Portugal; mmestevinho@med.up.pt \\ 3 Department of Onco-Hematology, Portuguese Institute of Oncology of Porto (IPO-Porto), \\ 4200-072 Porto, Portugal; mario.sousa.pimenta@ipoporto.min-saude.pt \\ 4 Centro de Investigação de Montanha (CIMO), Instituto Politécnico de Bragança, 5300-252 Bragança, Portugal \\ * Correspondence: leticia@ipb.pt; Tel.: +351-273303342
}

Received: 16 October 2020; Accepted: 2 November 2020; Published: 4 November 2020

check for updates

\begin{abstract}
Antibacterial resistance has become a challenging situation worldwide. The increasing emergence of multidrug-resistant pathogens stresses the need for developing alternative or complementary antimicrobial strategies, which has led the scientific community to study substances, formulas or active ingredients used before the antibiotic era. Honey has been traditionally used not only as a food, but also with therapeutic purposes, especially for the topical treatment of chronic-infected wounds. The intrinsic characteristics and the complex composition of honey, in which different substances with antimicrobial properties are included, make it an antimicrobial agent with multiple and different target sites in the fight against bacteria. This, together with the difficulty to develop honey-resistance, indicates that it could become an effective alternative in the treatment of antibiotic-resistant bacteria, against which honey has already shown to be effective. Despite all of these assets, honey possesses some limitations, and has to fulfill a number of requirements in order to be used for medical purposes.
\end{abstract}

Keywords: natural antibiotic; antimicrobial compounds; antibacterial action mechanisms; medical uses; honey-resistance; honey limitations

\section{Introduction}

In 1945, Alexander Fleming, Howard Florey, and Ernst Chain were awarded the Nobel prize for the discovery of the first broad-spectrum antibiotic in history: penicillin. Soon after this finding, they realized and warned of the ease with which bacteria could develop tolerance to that new remedy if it was misused [1]. Today, antimicrobial resistance has become a challenging situation, not only for human health, but also for human-connected animals, farms, food, water, and natural ecosystems worldwide [2-6].

Antibiotic resistance is a natural phenomenon that occurs when bacteria are exposed to antibiotics. Under the drug selective pressure, susceptible bacteria are killed or inhibited, while those bacteria that are naturally resistant, or that have acquired antibiotic-resistant features, have more opportunities to survive and multiply [3]. The overuse and improper use of antibiotics amplify and accelerate this circumstance.

Currently, there are bacteria which are able to resist almost all, or even all, the approved antimicrobial agents for their treatment. Consequently, some common infections have become very 
difficult, or even impossible, to treat $[3,7,8]$. The cost of treating antibiotic-resistant infections is much higher than that of treating susceptible ones [9]; the rise in the costs of the antibiotic therapy, derived from the necessity of using more expensive antibiotics, is coupled with a lengthier stay in hospital [3,5].

Further to the economic impact, an increase in mortality is another consequence of antibiotic resistance. Recent estimations based on data from EARS-Net (European Antimicrobial Resistance Surveillance Network) show that each year, approximately 33,000 people in Europe die as a direct consequence of infections caused by bacteria resistant to antibiotics [2].

Therefore, the research and development of a new generation of antimicrobials to alleviate the expansion of antibiotic resistance has become a priority [7]. However, testing a new antimicrobial before commercialization requires long time periods. Moreover, the current strategies to limit the appearance of resistance and to safeguard the efficacy of new antimicrobials entail a significant obstacle in drug development. Limiting their use, as much as possible, to those cases that do not respond successfully to existing products leads to a lack of profitability for pharmaceutical companies. In this way, the development of new antimicrobials is no longer an interesting activity [10].

Faced with this situation, the search for new alternatives has led to the scientific study of substances, formulas or active ingredients used before the antibiotic era. Honey has been traditionally used not only as a food but also with therapeutic purposes. One of the most common curative applications is the topical treatment of wounds, especially for its antimicrobial properties [11,12]. However, with the advent of antibiotics, the use of honey gradually declined. In recent decades, more and more scientific studies have been focused on revealing which compounds present in honey are related to its antibacterial activity, and the action mechanisms through which honey kills bacteria. The effectiveness of manuka honey as an antimicrobial agent has been extensively studied; for this reason, it has long been regarded as one of the most efficacious honey varieties known. However, several studies using other honey varieties also demonstrated promising antibacterial properties, and prove similar, or even greater, efficacy than manuka honey [13]. Despite the multiple studies on the antibacterial properties of honey, its use as an antibacterial agent continues to be underestimated.

The purpose of this review is to provide a comprehensive and updated overview of the scientific evidence that supports the use of honey as a potential antimicrobial alternative against drug-resistant bacteria, either alone or in combination with currently used chemotherapeutic agents. This work describes, briefly, the components responsible for the antibacterial effects of honey, the mechanisms of action that have been found to date, as well as the main studies that have demonstrated the efficacy of honey against resistant bacteria. In addition, it compiles the assays aimed at evaluating the possible appearance of honey-resistance, and the limitations which may prevent its use for medical applications.

\section{Factors Involved in Antibacterial Activity of Honey}

Honey is a natural sweet substance constituted by hundreds of compounds [13-15]. Honey composition is inherently rather variable and depends mainly on the floral source, although certain external factors, such as seasonal, environmental, as well as processing, manipulation, packaging and storage conditions, also play an important role $[15,16]$.

Some inherent characteristics, as well as a variety of substances which are part of honey composition, have been suggested as key elements responsible for its antimicrobial potential.

\subsection{Phisicochemical Characteristics with Antibacterial Effects}

\subsubsection{Osmotic Pressure and Low Water Activity}

Honey is an oversaturated solution of sugars including fructose, glucose, maltose, sucrose and other minor sugars, such as rhamnose, trehalose or erlose, which represent around the $80 \%(w / v)$ of its composition. Water is the second largest constituent of honey and may vary under normal conditions from $15 \%$ to $20 \%(w / v)$ depending on the botanical origin and the level of maturity of the honey, as well as on the processing and storage conditions $[15,17]$. 
The high concentration of sugars combined with the low moisture content are responsible for the low water activity values of honey, which range from 0.562 and $0.62[17,18]$, and cause osmotic stress in microorganisms [15,19]. Osmotic pressure induces the loss of water inside the bacteria, and once dehydrated, cells are unable to grow and proliferate [17]. In addtion, it has been suggested that the sugars present in honey interfere in bacterial quorum sensing [20,21], and more recently, it has been also demonstrated that osmotic pressure affects the ability of bateria to form biofilms [22].

Although a high concentration of sugar and a low water activity hamper the growth of many microorganisms, several studies have verified that artificial honey, prepared using a mixture of mono-and disaccharides at the same concentrations as those found in honey, is not as effective as honey in inhibiting bacterial growth [12,13,23-25].

\subsubsection{Acidity and Low $\mathrm{pH}$}

More than thirty-two organic acids have been identified in honey, including acetic, butyric, citric, formic, fumaric, glyoxylic, propionic, lactic, maleic, malic, oxalic and succinic acids [26]. However, gluconic acid, produced by the action of glucose oxidase on glucose, is the predominant one [27]. Due to the presence of these organic acids, honey is an acidic food, whose low value of $\mathrm{pH}$ (between 3.2 and 4.5), creates an unfavorable environment for microbial growth $[28,29]$.

\subsection{Compounds with Antibacterial Effects}

Honey contains several compounds in minor proportions which have been related to its bioactive properties. These substances can be specific to a variety of honey, or may be found in variable concentrations among different honey samples, depending primarily on their botanical origin [30].

\subsubsection{Hydrogen Peroxide}

Hydrogen peroxide $\left(\mathrm{H}_{2} \mathrm{O}_{2}\right)$ is produced when the enzyme glucose oxidase (added by honey-bees to the nectar), is activated on moderate dilution of honey, and reacts with glucose, producing gluconic acid and $\mathrm{H}_{2} \mathrm{O}_{2}[19,31]$. The maximum $\mathrm{H}_{2} \mathrm{O}_{2}$ concentration is reached at different dilutions according to the varieties of honey, but in most of honey samples, it occurrs at concentrations ranging from $15 \%$ to $50 \%$. In general, dark honeys often produce higher amounts of $\mathrm{H}_{2} \mathrm{O}_{2}$ than lighter ones, but the multifactorial process influencing the production and decomposition of $\mathrm{H}_{2} \mathrm{O}_{2}$ makes difficult to predict its concentration [32].

$\mathrm{H}_{2} \mathrm{O}_{2}$ is considered a true antibacterial, as it produces minimum inhibitory concentrations in bacteria in the range 10-1000 $\mu \mathrm{g} / \mathrm{mL}[31,33]$. The contribution of $\mathrm{H}_{2} \mathrm{O}_{2}$ to the antibacterial activity has been assesed in several studies, which demostrated that $\mathrm{H}_{2} \mathrm{O}_{2}$ removal using catalase significantly reduces the antibacterial potential of honey [33-35]. However, $\mathrm{H}_{2} \mathrm{O}_{2}$ levels in honey solutions are too low to have any direct antibacterial activity, so additive or synergistic mechanisms with other honey compounds are necessary to explain its activity [36]. The degradation of $\mathrm{H}_{2} \mathrm{O}_{2}$ catalyzed by ions such as $\mathrm{Cu}^{+}$or $\mathrm{Fe}^{2+}$, naturally present in honey, produces hydroxyl radicals (via Fenton reaction), which are more responsible for DNA damage than endogenous $\mathrm{H}_{2} \mathrm{O}_{2}$ [35,37]. Moreover, $\mathrm{H}_{2} \mathrm{O}_{2}$ hydrolysis also produces oxygen, which promotes the auto-oxidation of polyphenols by acting, under these circumstances, as pro-oxidant molecules responsible for bacteriostatic and DNA-damaging activities. Finally, $\mathrm{H}_{2} \mathrm{O}_{2}$ can react with benzoic acid, one of the phenolic acids present in honey, producing peroxy-acids, which are more stable and powerful antimicrobial agents than $\mathrm{H}_{2} \mathrm{O}_{2}$, and are able to resist the catalase activity $[35,37]$.

Although $\mathrm{H}_{2} \mathrm{O}_{2}$ is widely considered as the primary source of the antibacterial activity of honey, there are varieties whose main antibacterial mechanisms are non- $\mathrm{H}_{2} \mathrm{O}_{2}$ dependent.

\subsubsection{Phenolic Acids and Flavonoids}

Phenolic compounds are one of the largest groups of secondary metabolites that plants mainly synthesize for protection against biotic and abiotic stress and oxidative damage. These compounds are 
transferred via the nectar to honey. The phenolic compounds present in honey mainly belong to two families: phenolic acids and flavonoids [15,27].

Recent studies revealed that polyphenols are key components in the antimicrobial effects of honey [38-40]. The qualitative and quantitative dissimilarities observed in the phenolic profile of different honey varieties could justify the variations in their bioactivity [30,41]. In addition, the botanical origin may affect the profile of polyphenolic compounds, sufficiently to permit the discrimination among honey samples based on the predominance of some individual components [30,42,43].

The antibacterial activity of many flavonoids found in honey has already been described, as well as their main antibacterial action mechanisms [44-46], which in some cases are similar to those described for honey [14,47]. Nevertheless, their concentration in honey are not enough to produce, individually, the effects observed, and therefore their antibacterial properties are not due to their isolated action, but to their synergistic effects with other polyphenols, or other compounds, such as $\mathrm{H}_{2} \mathrm{O}_{2}$ [34,37]. Further investigations aimed at discovering the role of polyphenolic compounds and their direct antimicrobial impact are required.

\subsubsection{Methylglyoxal}

As was previously mentioned, there are honey varieties whose antibacterial activity is unrelated to the $\mathrm{H}_{2} \mathrm{O}_{2}$ content. Non-peroxide activity has been attributed to a variety of different compounds, among which are those known as 1,2-dicarbonyls. The 1,2-dicarbonyls are strongly reactive substances originating from caramelization or Maillard reactions in carbohydrate-rich foods [14].

Methylglyoxal (MGO) is a 1,2-dicarbonyls-breakdown-product of antimicrobial significance, and it has been identified as the main antibacterial compound in manuka honey [14]. The high levels of MGO found in this variety of honey are formed by the spontaneous dehydration of dihydroxyacetone, which is present at unusually high concentrations in the nectar of Leptospermum genus, including Leptospermum scoparium, Leptospermum polygalifolium, and some related Leptospermum species native to New Zealand and Australia [48-50]. Originally, it was assumed that manuka honey was the only variety that presents MGO in its composition. Nevertheless, several studies have evidenced that MGO is a compound that is also present in other types of honey, such as mire and polyfloral Nordic honey [51], different monofloral honey varieties (citrus, eucalyptus, acacia, chestnut, lime, rhododendron, strawberry tree, sulla, sunflower and thyme), honeydew and polyfloral honey from Italy [52], Finnish polyfloral honey samples [53], and honeydew Portuguese honey [54]. However, the concentrations of MGO in these honey varieties ranged between 0.2 and $166 \mathrm{mg} / \mathrm{kg}$, while in manuka honey, this compound is found, in general, in significantly higher concentrations (ranging from 38 to $1541 \mathrm{mg} / \mathrm{kg}$ ) [19].

The antibacterial action mechanisms of MGO have not been completely elucidated, but go through inducing alterations in the structure of bacterial fimbriae and flagella, which would limit bacteria adherence and motility, as well as producing damage to cell membranes, and the shrinking and rounding of cells [55].

\subsubsection{Bee Defensin-1 Peptide}

Bee defensin-1 is an antimicrobial peptide (AMP) found in bee hemolymph and is produced in their salivary glands, so it is incorporated into honey during the primary processing. Similar to other AMPs, such as apidaecin, abaecin or hymenoptaecin, defensin makes up part of bee the immune system [56-58]. The presence of bee defensin-1 in honey has not yet been systematically investigated, and widespread quantitative data of this peptide have not yet been established. It has been detected in the medical-grade honey Revamil, and in manuka honey it appears to be modified, which is thought to be the result of interaction with MGO, although its concentration in this variety is not significant [59-61]. Defensin-1 has been also detected in different varieties of honey from several regions of Slovakia, and more recently in eucalyptus honey samples from Ecuador [22,62]. The content of defensin- 1 was variable among the honey varieties, and curiously in samples with similar floral sources, but different 
geographical origins, which indicates that defensin- 1 content might be associated with the genetic diversity of honeybees [62].

Defensin-1 displays activity against different microorganisms, including Gram-positive and Gram-negative bacteria; however, its efficacy against multi-drug resistant bacteria seems to be limited at the concentration present in honey $[59,60]$. The antibacterial action mechanisms of bee defensin- 1 have not been completely elucidated, but it is suggested that they might act by creating pores within the bacterial cell membrane, resulting in cell death, as happens with other species' defensins [14]. Moreover, it has recently demonstrated that defensin-1 plays an important role in the antibiofilm activity of honey [22].

\section{How Honey Acts against Bacteria: Antibacterial Action Mechanisms}

Despite the numerous studies on the antibacterial properties of honey, the lack of comprehensive evidence explaining the mechanisms through which honey interferes with bacteria, limits, partly, its application as an antibacterial agent $[12,63,64]$. Honey is a very complex substance, containing hundreds of compounds that cause specific and distinct effects on microorganisms (Figure 1). The mode of action of honey against bacteria differs among Gram-positive and Gram-negative microorganisms, some studies hypothesized that at least some cellular targets might be broadly specific for each class of bacteria $[12,13,23]$. However, given the complexity of the matrix, there are probably several mechanisms that have not been described yet.

In terms of understanding the mechanisms of action of honey upon bacteria, most of the research has been undertaken using manuka honey. Nevertheless, more and more studies are being carried out with other, different varieties (Figure 1).

\subsection{Structural and Morphological Changes}

One of the earlier attempts to reveal honey's action mechanisms were centred on observable characteristics by using scanning and transmission electron microscopy. In methicillin-sensitive Staphylococcus aureus and methicillin-resistant S. aureus (MRSA), it was verified that manuka honey did not induce a significant cellular lysis, few surface changes were found and the majority of the cells retained a smooth surface after four hours of treatment [12]. On the contrary, Pseudomonas aeruginosa cells exposed to manuka honey exhibited widespread structural damage and large membrane bubbles, which led to cell lysis and bacterial death [23]. This result was verified by genomic analysis, showing that manuka honey treatment causes a reduction in the expression of $\operatorname{OprF}$, an integral membrane protein that is essential for the structural stability of the cell envelope in Gram-negative bacteria [65]. After these studies, it was found that manuka and kanuna honey exerted very different changes on the cellular morphology of Bacillus subtilis, Escherichia coli, S. aureus, and P. aeruginosa. While for the first three bacteria a significant cell shortening was observed, in the case of P. aeruginosa, cells appeared longer than usual, which is possibly a reflection of the cell envelope damage that likely happened [66]. More recently, flow cytometry also confirmed the previous results. The treatment time and the honey concentration were identified as key factors in the induction of membrane injury in S. aureus and E. coli cells. The differences observed among Gram-positive and Gram-negative bacteria were also highlighted in this study [64]. Membrane permeabilization after manuka honey exposition was also verified by flow cytometry assays in P. aeruginosa [25].

These mechanisms are not exclusively attributable to manuka honey, and several honey varieties have been demonstrated to produce morphological and structural alterations on bacteria as one of their first effects (Figure 1). Buckwheat honey and wildflower honey were demonstrated to induce a rapid disruption of the cell wall of E. coli, which was honey concentration- and treatment time-dependent [67]. Structural and morphological changes, such as altered shape, modified surface layers, cellular debris, increased vacuoles, and/or with irregular shrunken cytoplasm, as well as the presence of electron dense material, were also described in E. coli cells after treatment with citrus, clover and marjoram honey [68]. Agastache honey caused extensive cell lysis and membrane disruption in MRSA and 
E. coli [69]. Avocado, chestnut and polyfloral honey samples induced membrane injury upon S. aureus and E. coli with differences among bacterial types. While the effect of the different honey samples on $S$. aureus membrane integrity was limited, in the case of E. coli cells, the results obtained confirm a more meaningful damage. Under similar treatment conditions, these three honey samples caused more relevant changes in membrane integrity than manuka honey [47]. On the other hand, no morphological changes in P. aeruginosa cells were observed after Corsican honey exposure, despite the fact that this bacterium was sensitive to the different varieties tested [35].

In addition, related to changes in bacterial morphology, it was verified that manuka honey suppresses $P$. aeruginosa flagellum gene expression, by impacting on regulatory and structural genes, which entails a reduction in protein expression, and means a significant reduction in flagellated cells. This finding has consequences beyond morphological alterations in bacterial cells, since flagellum is critical for pathogens to establish and produce invasive infection, so honey can also reduce the pathogenic potential of infecting bacteria [70].

\subsection{Alterations of Bacterial Membrane Potential}

Membrane potential plays an essential role in several bacterial physiological processes. The loss of the equilibrium of ion concentration inside and outside of bacteria may affect to their viability [71].

Three recent studies described, for the first time, that different honey varieties (manuka, avocado, chestnut and a polyfloral honey) induce significant membrane depolarization in P. aeruginosa, S. aureus, and E. coli $[25,47,64]$. This finding has great significance, since a collapse in the membrane potential means that bacteria are not able to generate the energy required to carry out their normal physiological processes, such as the correct spatial organization of cell division proteins and regular cell division function [72], as well as to drive the mechanisms necessary for its survival, such as some multidrug efflux pumps [25] (Figure 1).

\subsection{Bacterial Cell Cycle and Cell Growth Changes}

The first studies using scanning and transmission electron microscopy revealed that the main effect of manuka honey upon methicillin-sensitive S. aureus and MRSA involved the interruption of the cell cycle. Bacterial cells were unable to separate, which resulted in an accumulation of arrested cells with a fully formed septum [12]. It was suggested that septa were formed prematurely in the cell cycle, and cell division was then interrupted because mandatory cellular events had not been completed yet. Alternatively, cell division might have been prevented due to the effects of manuka honey on autolysin activity, which normally controles the septum rupture to produce the two daughter cells [24].

In addition, it was corroborated that manuka honey induced a dose-dependent extension of the lag phase of cell growth of B. subtilis, E. coli, and S. aureus when they were treated with manuka honey. This growth behavior was also observed when these bacterial cultures were exposed to MGO, and was not detected after the treatment of bacteria with other honey varieties (clover or kanuka honey); so, the extended duration of lag phase was supposed to be due to MGO [66]. In contrast, P. aeruginosa showed a markedly different pattern of growth inhibition to the other three bacteria; very little or no lag-phase extension was observed after honey treatment, except for the treatment with clover honey [66].

Finally, honey also affects bacterial DNA. This effect, observed on B. subtillis and E. coli, was related to the interactions of $\mathrm{H}_{2} \mathrm{O}_{2}$ with polyphenols as active intermediates that are necessary to confer oxidative action of $\mathrm{H}_{2} \mathrm{O}_{2}$ through hydroxyl radical production [37]. This mechanism was supported by transmission electron microscopy observations, which revealed "ghost" E. coli cells lacking DNA, after citrus honey treatment [68]. Moreover, exponentially growing P. aeruginosa cells presented condensed chromosomes after treatment with manuka honey, which suggest that this variety of honey inhibits DNA replication in these cells by non-oxidative stress mechanisms $[25,66]$. 


\subsection{Disruption of Bacterial Metabolism}

Despite the fact that very few studies have been carried out to evaluate the effect of honey on the metabolic activity of bacteria, the concordance of the results obtained indicates that honey plays a key role in the metabolic disruption of both Gram-positive and Gram-negative bacteria. Genomics and proteomics demonstrated that manuka honey is able to reduce the expression of genes and proteins involved in the energy metabolism of MRSA [73]. These findings were corroborated by other flow cytometry assays to evaluate the repercussion upon metabolic bacterial physiology of reference strains of $S$. aureus and E. coli induced by manuka honey, and also by other three honey varieties (avocado, chestnut and polyfloral) $[47,64]$. However, differences in bacterial response, depending on the honey type and the concentration tested, were observed, probably due chemical composition variances among samples. Metabolic disruption induced by manuka honey seemed to be an irreversible effect, whereas in the case of the other honey varieties, bacteria appear to reprogram their metabolism in response to the environmental stress, being able to progressively recover metabolic activity, at least partially, at the end of honey exposure [47].

Moreover, other underlying mechanisms could also affect bacterial metabolism. Studies on E. coli [74,75], as well as on P. aeruginosa [75,76] and S. aureus [75], confirmed the effect of manuka honey as an iron-chelator, generating a limiting environment of this element, which is essential for bacterial metabolism and survival. Furthermore, membrane potential is also a fundamental process in energy generation for bacteria. It has been described that honey induces membrane depolarization $[25,47,64]$, which may impede the ability of bacteria to generate the energy required for several processes [25].

\subsection{Effect on Efflux Pumps Activity}

Multidrug efflux pumps are cell membrane glycoproteins that can eject different classes of compounds across bacterial membranes; for this reason, they are one of the most important mechanisms of drug resistance, since antibiotics are not capable of reaching the concentration at which they are active within the bacteria $[77,78]$.

Some natural products, including plant extracts, essential oils or isolated compounds, are capable of inhibiting or modifying the efflux pumps' activity [78]. In this context, manuka honey has been proven to induce alterations in the expression of genes belonging to the evgAS regulon, related to bacterial adaptive responses to acid, osmotic and drug resistance [74]. The results obtained in this first study were partly corroborated by later research; another study using different honey types (clover, citrus and marjoram) demonstrated that depending on the honey variety, the gene expression profile was different. $\operatorname{Evg} A$ expression was upregulated after the treatment with clover honey, but it was downregulated after citrus or marjoram honey-exposure. [68]. The dissimilarities in the expression patterns may reflect compositional differences among honey varieties and/or differences in their action mechanisms, since the major antimicrobial activity of manuka honey is not related to $\mathrm{H}_{2} \mathrm{O}_{2}$, while the other honey varieties were shown to be mainly peroxide-dependent [68].

A more recent study, using flow cytometry, proved that manuka honey was able to disrup efflux pump activity of an AG100 progeny strain of E. coli, which over-expresses several efflux pumps when exposed to high concentrations of tetracycline. Manuka honey blocked efflux pump activity, following a dose-dependent tendency [64]. This finding seems to differ from those previously described. These discrepancies may be justified by a lack of correlation between gene expression and bacterial physiological response or by other mechanisms not directly related to the genes involved in bacterial defence and adaptative reponse. It was suggested that this effect could be associated with the metabolic disruption, since antibiotic efflux is an energy-dependent mechanism [64]. More recently, Bouza et al. hypothesized that manuka honey could increase the drug uptake due to the membrane potential collapse, and the increase in membrane permeabilization, which together would enhance the potency of antibiotics [25]. These mechanisms justify why manuka honey is able to restore the tetracycline antibiotic activity against bacterial strains that would otherwise be resistant $[25,79]$. 


\subsection{Bacterial Quorum Sensing Alterations}

Quorum sensing is the cell to cell communication system used to coordinate and regulate the behavior of cell populations. Many bacterial physiological functions, such as luminescence, virulence, motility, sporulation or biofilm formation, are regulated by quorum sensing systems [20]. For this reason, the interruption of bacterial quorum sensing is recognized to alleviate virulence, and is considered to be a potential new alternative to treat infections caused by pathogenic bacteria [20].

Only a few studies on the effect of honey on inhibition of quorum sensing have been published. Nevertheless, the results demonstrate that some genes involved in this bacterial interconnection mechanism, as well as other virulence genes, are downregulated following exposure to honey $[21,25,68,73,80]$. Furthermore, honey was able to enhance the anti-quorum sensing activity of other substances, such as curcumin, when they were used in combination [81].

Additionally, the secretion of $\mathrm{N}$-acyl-1-homoserine lactones and other quorum sensing regulating or signalling substances (pyocyanin, pyochelin and pyoverdine) is significantly reduced in response to honey exposure [20,81]. It was suggested that this inhibitory activity seems to be related to the aqueous phase of the honey instead of either the total or individual phenolic content [20] (Figure 1). In addition, pyocyanin, pyochelin and pyoverdine act as iron-chelating molecules or siderophores, which are central to bacterial proliferation in the host environment, and are inherently linked to pathogen virulence $[13,76]$. Honey-treatment mediates a marked reduction in siderophore production, which is accompanied by the reduction in the expression of genes involved in quorum sensing. This fact demonstrates the global impact that gene downregulation exerts on the expression of virulence factors [13].

\subsection{Biofilm Inhibition}

Biofilms constitute an extraordinary microbial drug-resistance mechanism, which is composed of an assemblage of microbial cells that are irreversibly associated with a surface and enclosed in a matrix of self-produced polysaccharide material. Included in biofilms, bacteria are several times more resistant to antibiotics than planktonic cells, which makes them extremely difficult to destroy $[82,83]$.

The effects of different varieties of honey samples on bacterial biofilms have been assessed in various studies, and the results indicate that honey is effective in disturbing the biofilm strengthening in drug-sensible and drug-resistant bacteria.

First of all, honey is able to prevent the formation of biofilms, from both Gram-negative and Gram-positive bacterial species, most likely via a non-specific mechanism such as the inhibition of bacterial growth, and the reduction in the biofilm biomass [22,36,82,84-87], which are consequences of the osmotic stress, coupled with the low pH and the presence of $\mathrm{H}_{2} \mathrm{O}_{2}$ of honey (Figure 1). This effect is dependent on concentration - when honey concentration is not enough, the biofilm formation could be enhanced $[36,87]$.

In addition, when the biofilm is already established, honey significantly reduces its metabolic activity, probably due to the disruption of the metabolic activity of individual bacterial cells-this mechanism is also suggested to explain the inhibition of biofilm development when it is forming $[36,88]$. In this phase, honey also decreases the number of viable cells $[36,82,84,85,87]$.

Finally, gene expression analysis also confirmed the effect of honey on the expression of different genes related to the formation and the development of biofilms [68]. Honey might prevent the colonization of host tissues due to the downregulation of genes encoding binding proteins $[73,85,88]$, and the inhibition of the expression of genes encoding a glucosamine polymer [19]. 


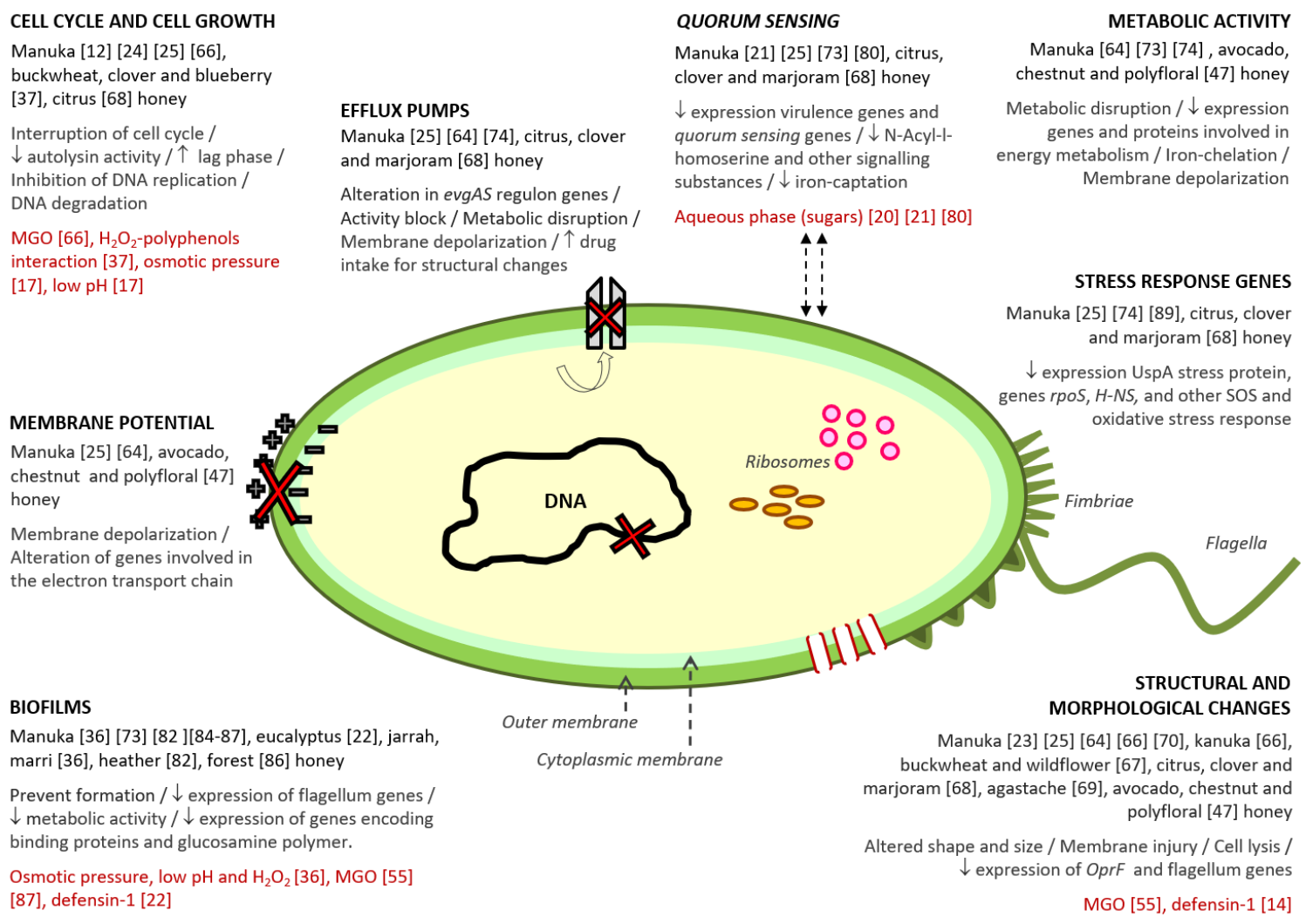

Figure 1. Antibacterial action mechanisms described for honey. Within each mechanism, the following information has been collected: (i) varieties of honey in which the mechanism was detected; (ii) the different effects related to the mechanism; (iii) the compound/s or honey characteristics associated to the mechanism, and (iv) the reference number of the studies from which the information was extracted.

\subsection{Effects on Bacterial Stress Response}

Several studies have demonstrated that honey exposure also affects the expresion of different genes involved in bacterial stress response. Manuka honey exposure generates the downregulation of the universal stress protein UspA in MRSA, which reduces the ability of bacteria to survive under cellular and metabolic stress conditions [89].

In addition, other studies have demonstrated similar effects in genes related to cell stress survaival mechanisms, namely rpoS and $H-N S$, after the exposure of $E$. coli cells to citrus, clover, and marjoram honey samples [68]. These results were in contrast to those previously described by Blair et al., who showed marked upregulation in the same genes of E. coli following manuka honey-treatment [74]. A more recent study demonstrated that manuka honey induced strong upregulation in a wide range of genes involved in the emergencyand the oxidative stress response of P. auregonisa cells [25].

Taking into account all these results, it is feasible to think that the variances in expression pattern may be justified by the differences in the antimicrobial mechanisms of the honey varieties tested, and the variable effects they can induce on certain genes.

\section{Honey against Antibiotic-Resistant Bacteria}

It is well demonstrated that honey inhibits a broad range of bacteria, and is equally as effective against antibiotic-susceptible bacteria as it is against those that are resistant [13,30,90-92]. Nevertheless, since all the results obtained from in vitro studies always cannot be reproduced under in vivo conditions, very few studies of this type have been undertaken (Table 1).

Paradoxically, one of the first assays to test the efficacy of honey against antibiotic-resistant microorganisms was carried out in vivo, to heal a hydroxyurea-induced leg ulcer colonized by MRSA, 
using manuka honey. This study recognized that honey possesses antibacterial properties upon resistant bacteria, and can also promote effective wound healing [93]. Following this study, a significant amount of work using manuka honey confirmed its effects against MRSA in vitro [24,94-100] and in vivo [101], vancomycin-resistant S. aureus [91], and vancomycin-resistant enterococci (VRE) [100]. MRSA and VRE are considered the foremost pathogens that often infect chronic wounds in the earlier stages [96]. In Gram-negative bacteria, the effects of manuka honey has also been observed against extended-spectrum beta-lactamase (EBSL)-producing E. coli [94,102], ESBL-producing Klebsiella pneumoniae [94,103,104], and carbapenemase-producing Klebsiella pneumoniae [94], as well as against multidrug-resistant $P$. aeruginosa [94]. Manuka honey has also demonstrated antimicrobial activity against Ureaplasma paroum and Ureaplasma urealyticum, pathogens without a cell wall with high levels of intrinsic and acquired antibiotic resistance [105]. Moreover, preceding in vivo studies confirmed the efficacy of Medihoney (the medical grade manuka honey) in the prevention of catheterisation-associated infections [106].

Manuka honey has undoubtedly been shown to be effective against a broad spectrum of antibiotic-resistant bacteria, and it is the variety most used in antimicrobial activity assays. For these reasons it is commonly used as "control honey". However, studies with other varieties confirm that this kind of honey is not the only one with potentialities in the fight against resistant bacteria (Table 1).

Another medical-grade honey, Revamil, showed antibacterial activity against various antibiotic-resistant wound pathogens $[60,61,107]$. The data indicated in these studies that the antibiotic sensitive counterparts for the tested microorganisms were no more or less susceptible to honey treatment. However, bactericidal effects required prolonged honey-exposure of the target microorganism [61]. In addition, in vivo studies demonstrated that this type of honey was able to reduce the microbial colonization of skin of healthy volunteers 100-fold [107]. More recently, L-Mesitran products, formulated with medical-grade honey, demonstrated in vitro their activity against MRSA [99], and in vivo their promising applicability to treat chronic diabetic ulcers, preventing amputations derived from antibiotic-resistant infections [108].

Apart from manuka honey and medical-grade-honey-based formulations, other works proved that "common" honey samples play an important role as antibacterial agents too. E. coli, S. aureus, and different species of genus Bacillus and P. aeruginosa resistant to several antibiotics, were susceptible, in vitro, to honey from aromatic and medicinal plants from Morocco [109].

After this early work, the scientific community realized the potential of different honey types in the treatment of antibiotic-resistant bacteria, and numerous studies screened different honey varieties from all over the world. Ulmo tree honey induced greater inhibitions zone and showed lower minimal inhibitory and minimal lethal concentrations than manuka honey against reference and clinical isolates of MRSA. The activity of this honey type was attributed to its strong $\mathrm{H}_{2} \mathrm{O}_{2}$ antimicrobial effect [110]. To provide a better insight into the involvement of $\mathrm{H}_{2} \mathrm{O}_{2}$ on bacterial growth, Brudzynski and Lanniganwe tested different varieties of Canadian honey (sweet clover, blueberry, and buckwheat, previously selected for their higher bacteriostatic activity), against MRSA and vancomycin-resistant Enterococcus faecium [111]. All bacterial strains were sensitive to honey bacteriostatic action. The study also confirmed that the generation of hydroxyl radical from the $\mathrm{H}_{2} \mathrm{O}_{2}$ which is present in honey caused growth inhibition of the both clinical isolates [111].

The effectiveness of black seed, beri and shain honey in treating twenty-five wound isolates of MRSA and other wound pathogens was compared to manuka honey efficacy [112]. Manuka honey showed better antibacterial activity against all tested clinical isolates as compared to the other varieties. However, the three varieties revealed good in vitro performance (MIC values did not exceed $11 \%(w / v)$ ), and black seed honey exhibited a comparable antibacterial activity to manuka honey [112].

Different Scottish honey samples (blossom, heather, Highland, and Portobello Orchard) exhibited antimicrobial activity upon clinical isolates of penicillin-resistant Acinetobacter calcoaceticus, S. aureus, P. aeruginosa and E. coli [38]. These honey varieties were not as effective as manuka honey in inhibiting bacterial growth. However, Highland honey and Portobello honey showed good results. Antimicrobial 
activity appeared to be influenced, but not completely explained, by phenolic compound content. Characteristic polyphenol components in the different honey samples, as well as novel glycoside derivatives of fatty diacids, which may contribute to their antimicrobial activities, were found [38].

Table 1. Different honey varieties and honey-based products against antibiotic-resistant bacteria, type of study accomplished (in vitro or in vivo) and reference number of the studies from which the information was extracted.

\begin{tabular}{|c|c|c|c|}
\hline Honey Type. & Microorganism & Type of Study & Reference \\
\hline \multirow{9}{*}{ Manuka } & \multirow[t]{2}{*}{ MRSA } & $\begin{array}{l}\text { in vivo } \\
\text { hydroxyurea-induced leg ulcer } \\
\text { leg ulcer }\end{array}$ & $\begin{array}{c}{[93]} \\
{[101]}\end{array}$ \\
\hline & & in vitro & {$[24,69,94-100,113]$} \\
\hline & VRSA & in vitro & [91] \\
\hline & VRE & in vitro & [100] \\
\hline & ESBL-E. coli & in vitro & {$[94,102]$} \\
\hline & ESBL-K. pneumoniae & in vitro & {$[94,103,104]$} \\
\hline & CARB-K. pneumoniae & \multirow{2}{*}{ in vitro } & \multirow{2}{*}{ [94] } \\
\hline & MDR-P. aeruginosa & & \\
\hline & $\begin{array}{l}\text { Ureaplasma parvum } \\
\text { U. urealyticum }\end{array}$ & in vitro & [105] \\
\hline Medihoney & $\begin{array}{l}\text { Bacteria related to } \\
\text { catheterization infections }\end{array}$ & $\begin{array}{l}\text { in vivo } \\
\text { catheterization infections }\end{array}$ & [106] \\
\hline \multirow[t]{2}{*}{ Revamil } & $\begin{array}{c}\text { MRSA } \\
\text { MRSE } \\
\text { ESBL-E. coli } \\
\text { ESBL-P. aeruginosa } \\
\text { ESBL-E. cloacae } \\
\text { ESBL-K. oxytoca } \\
\text { VREF }\end{array}$ & in vitro & {$[60,61,107]$} \\
\hline & Colonizing skin bacteria & $\begin{array}{c}\text { in vivo } \\
\text { skin colonization }\end{array}$ & [107] \\
\hline & MRSA & in vitro & [99] \\
\hline L-Mesitran & $\begin{array}{l}\text { MDR-P. aeruginosa } \\
\text { MDR-streptococci } \\
\text { AR-polymicrobial infection } \\
\text { PR-polymicrobial infection } \\
\text { MDR-E. coli }\end{array}$ & $\begin{array}{c}\text { in vivo } \\
\text { chronic diabetic ulcers }\end{array}$ & [108] \\
\hline \multirow{4}{*}{$\begin{array}{l}\text { Aromatic-and- } \\
\text { medicinal-plants honey }\end{array}$} & MDR-E. coli & \multirow{4}{*}{ in vitro } & \multirow{4}{*}{ [109] } \\
\hline & MDR-S. aureus & & \\
\hline & MDR-Bacillus spp. & & \\
\hline & MDR-P. aeruginosa & & \\
\hline Ulmo tree & MRSA & in vitro & [110] \\
\hline $\begin{array}{c}\text { Sweet clover Blueberry } \\
\text { Buckwheat }\end{array}$ & $\begin{array}{l}\text { MRSA } \\
\text { VREF }\end{array}$ & in vitro & [111] \\
\hline $\begin{array}{l}\text { Black seed Beri } \\
\text { Shain }\end{array}$ & MRSA & in vitro & [112] \\
\hline $\begin{array}{l}\text { Blossom } \\
\text { Heather } \\
\text { Highland } \\
\text { Portobello }\end{array}$ & $\begin{array}{l}\text { PR-A. calcoaceticus } \\
\text { PR-S. aureus } \\
\text { PR-P. aeruginosa } \\
\text { PR-E. coli }\end{array}$ & in vitro & {$[38]$} \\
\hline
\end{tabular}


Table 1. Cont.

\begin{tabular}{|c|c|c|c|}
\hline Honey Type. & Microorganism & Type of Study & Reference \\
\hline $\begin{array}{c}\text { Sage } \\
\text { Chestnut } \\
\text { Locust tree } \\
\text { Lime tree } \\
\text { Indigo bush } \\
\text { Rapeseed } \\
\text { Maple } \\
\text { Mint } \\
\text { Spring and Autumn } \\
\text { pasture } \\
\text { Maple } \\
\text { Fir honeydew }\end{array}$ & $\begin{array}{c}\text { MRSA } \\
\text { MDR-P. aeruginosa } \\
\text { ESBL-E. coli } \\
\text { MDR-A. baumannii }\end{array}$ & in vitro & [114] \\
\hline $\begin{array}{l}\text { Agastache } \\
\text { Tea-tree } \\
\text { Jelly bush } \\
\text { Jarrah }\end{array}$ & MRSA & in vitro & [69] \\
\hline $\begin{array}{c}\text { Avocado Chestnut } \\
\text { Eucalyptus } \\
\text { Rosemary } \\
\text { Thyme } \\
\text { Polyfloral }\end{array}$ & $\begin{array}{c}\text { MRSA } \\
\text { MDR-S. pyogenes } \\
\text { MDR-E. coli } \\
\text { MDR-P. aeruginosa }\end{array}$ & in vitro & [30] \\
\hline Germania & MRSA & in vitro & [113] \\
\hline
\end{tabular}

In the case of diverse Croatian honey samples (sage, chestnut, locust tree, lime tree, indigo bush, rapeseed, maple, mint, Spring and Autumn pasture, and maple and fir honeydew honey samples), variable effects upon bacterial strains of MRSA, multidrug-resistant P. aeruginosa, ESBL-producing E. coli and multidrug-resistant Acinetobacter baumannii were observed [114]. Fir honeydew and mint honey were the honey varieties which showed significantly higher antibacterial activity against all bacteria. On the other hand, it was assumed that locust tree, rapeseed and spring pasture honey samples did not have the necessary ingredients or synergy among active components to affect bacteria [114].

Afterwards, antimicrobial activity of agastache honey was compared with those of manuka, tea-tree, jelly bush, super manuka (MGO-400), and jarrah honey [69]. All samples showed some antibacterial activity upon reference and clinical isolates of MRSA, as well as upon other wound pathogens. However, inhibitory and bactericidal effects varied, depending on the bacterial species, strain, and the type of honey; the effective concentrations ranged from $3.12 \%$ to $25 \%(w / v)$. Hydrogen peroxide contributed to the antimicrobial activity of agastache, super manuka, and jarrah honey, but not in manuka and jelly bush honey, while the tea tree honey activity was largely $\mathrm{H}_{2} \mathrm{O}_{2}$-based [69].

Spanish honey samples of several botanical origins (avocado, chestnut, eucalyptus, rosemary, thyme, polyfloral) also demonstrated in vitro efficacy against MRSA and other pathogenic bacteria (Streptococcus pyogenes, E. coli, and P. aeruginosa) with varying degrees of antibiotic-resistance. However, effective concentrations were rather variable, ranging between 0.05 and $0.40 \mathrm{~g} / \mathrm{mL}$, depending on the honey variety and the microorganism tested [30].

One of the last studies to evaluate the antibacterial potential of honey showed that not all honey varieties have a good performance. In vitro diluted Germania honey was relatively ineffective against MRSA, and was significantly less effective than manuka honey even when undiluted [113]. This study highlights the importance of testing and selecting an adequate variety of honey, especially when it is going to be applied for clinical purposes. 


\section{What about Honey-Resistance Acquisition?}

One of the biggest conundrums in using an antibiotic is how long it will be effective in treating the target microorganism. Usually, antibiotics or chemotherapeutic substances aim at a particular process, structure or physiological mechanism, and in this way provide a specific evolutionary pressure to which bacteria are easily able to adapt [13]. Honey is a natural substance with a complex composition, which turns out to be one of the main advantages for its use as an antimicrobial agent. The presence of hundreds of compounds, which might act additively or synergistically in multiple bacterial targets, makes it difficult for bacteria to adapt to them, and therefore, make the development of resistance more complicated $[13,87]$.

Some studies have been carried out using manuka honey to evaluate the possibility that its extensive use might provide a selective pressure for the emergence of honey-resistant bacteria. Blair et al. were the first in demonstrating that $S$. aureus and P. aeruginosa did not acquire resistance to honey when they were continuously exposed to sub-lethal concentrations of manuka honey. This study refuted the theory that bacteria could rapidly gain resistance to $\mathrm{MGO}$, as the main antimicrobial substance present in manuka honey [74]

Afterwards, Cooper et al. accomplished in vitro assays with reference to clinical isolates of different bacteria by repeated cultivation in a sub-lethal concentration of honey for ten consecutive days, or by incubation in stepwise increasing concentrations over twenty-eight days. The results indicate that it was not possible to generate honey-resistant mutants in a short-term stepwise resistance training period. The same results were observed when bacteria were exposed to increasing concentrations of honey in a long-term assay. However, the honey MICs increased for P. aeruginosa, MRSA, Staphylococcus epidermidis and E. coli by factors of 1.4, 1.6, 1.7 and 2.1, respectively- even so, these changes were not persistent [115].

More recently, Mokhtar et al. evidenced that long-term exposure of different strains of S. aureus, S. pyogenes, P. aeruginosa, E. coli, MRSA and S. epidermidis to manuka honey was not able to generate isolates with a reduced susceptibility to honey following a similar time frame in which resistance to macrolides was generated [97]. Moreover, it was suggested that the iron chelation capacity of manuka honey affects multiple diverse physiological processes in bacteria and would contribute to the lack of bacterial resistance to honey [75].

Despite all these encouraging findings, it is necessary to take into account the results reported by Camplin and Maddocks, which demonstrate that P. aeruginosa isolates that recovered from honey-treated in vitro biofilms can develop sustained, increased resistance, which might be due to the appearance of small colony variants within the microbial population [116].

In addition, it has been observed that honey acts synergistically with several antibiotics, reducing the doses required to inhibit bacterial growth or reverting the antibiotic-resistance previously acquired. The synergism or additive effects between manuka honey and tetracycline, imipenem, mupirocin and gentamycin has been described for P. aeruginosa $[79,117]$, as well as between manuka honey and oxacillin, rifampicin, linezolid, tetracycline, imipenem, mupirocin and vancomycin for susceptible S. aureus and MRSA $[63,79,95,98,117,118]$, which demonstrates that manuka honey interacts positively with different antibiotic classes to inhibit bacterial growth. In addition, in combination with oxacillin, manuka honey was able to restore the susceptibility of MRSA to the antibiotic [95]. The mechanisms by which synergism occurs have not been described in detail. It has been suggested that this could be, at least partly, due to an increase in hydroxyl radical production due to the presence of honey. However, other factors must be involved because peroxide activity in manuka honey is not essential for the complete inhibition of bacterial growth [63]. Moreover, the presence of MGO increased the intracellular accumulation of the antibiotic, enhancing its activity against bacteria [118].

Further, manuka honey-antibiotic synergism also affects biofilm formation, especially with rifampicin $[63,119]$. Since manuka honey alters the levels of protein-synthesis components, including ribosomal proteins, this effect is probably due to a 'like plus like' effect on the protein synthesis pathway $[63,74,90]$. 


\section{Limitations of the Use of Honey in Therapy}

The extensive scientific evidence proves that honey may offer distinct advantages over the chemotherapeutic substances currently used. However, despite being a potential antimicrobial agent, its use in medicine remains underestimated due to a series of limitations, mainly related to compositional and application aspects.

Honey is a natural substance with a rather variable composition, which depends primarily on its botanical origin [30]. Compositional variances condition its bioactive potential and hamper its further application for clinical purposes [120,121]. This fact highlights the importance of selecting an appropriate variety of honey, which means that a previous screening is necessary in order not only to quantify but also to determine profiles of bioactive substances [19,30]. In addition, it is necessary to consider that, although minor, there is a possibility that honey might induce negative effects, either by ingestion [122,123] or by topical use, mainly related to the presence of Clostridium botulinum spores, which have occasionally been found in honey [19,124,125]; however, to date, no cases of wound infection due to C. botulinum spores related to the use of non-irradiated honey were reported. Moreover, honey for medical uses must be free of any form of contamination, such as herbicides, pesticides, heavy metals, and spores-to meet all these criteria, honey must be collected in organic regions, as well as following strict quality, processing, and storage standards and regulations, in order to ensure its safety [108].

On the other hand, the absence of standardization of antibacterial activity, and the incomplete knowledge of the active components, and how they interact and act against bacteria, are the major limitations for the application of honey in medicine [61,126]. So, more studies attempting to detail the antibacterial effects of the different components present in honey, as well as to elucidate the molecular mechanisms underpinning the observed effects, are necessary. In addition, robust, large-scale clinical trials are imperative to confirm that honey's efficacy is similar in vitro to that in in vivo assays. In this regard, the feasible application of honey in medicine should be considered. As an antibacterial agent, honey is not a systemic therapy-to produce an effect, it must be in contact with the target microorganism, which restricts it use mainly to treat wounds infections and as a topical preventive at sites where microorganisms could cause an infection $[13,14,107,126]$.

Some of the limitations described are overcome by medical-grade honey varieties, which have been approved as medical products for wound care [61]. Medical grade honey is sterilized, produced under rigorous standards of hygiene, without contaminating pesticides or pollutants in its composition, and standardize under different defined criteria [96].

\section{Conclusions}

The emergence and rapid spread of antibiotic-resistant bacteria is one of the most pressing concerns not only for human health, but also for human-connected animals, farms, food, water, and natural ecosystems worldwide. The limitations posed by the development and commercialization of new-generation antibiotics have led to a relative absence of effective options on the market and have forced the search for new alternatives. Numerous scientific studies are being carried out to evaluate the antimicrobial potential of different substances, formulas or active ingredients traditionally used before the advent of antibiotics, and honey is one of them.

Honey has been used since ancient times for its nutritional and medicinal properties, especially for its antimicrobial activity. Several studies have scientifically demonstrated its efficacy against pathogenic bacteria, both sensible-and-resistant to antibiotics. In its composition, honey presents hundreds of compounds which act upon several target sites, additively or synergistically, since when used in isolation, at the concentrations found in honey, many of them do not produce effects upon bacteria. This characteristic could be behind the difficulty of bacteria to acquire honey-resistance. In addition, the combined used of honey and antibiotics reduces the concentrations of drugs necessary to achieve efficacy, thus limiting the likelihood of developing resistance, and reverting the susceptibility of some resistant bacteria to antibiotics. 
All these assets suggest that honey might find a place in clinical practice as part of combination antimicrobial therapies with systemically administered antibiotics to treat multidrug-resistant bacteria, especially in topical applications. However, the honey used for medical purposes must be guaranteed, in its antibacterial efficacy and its safety for patients.

Author Contributions: Conceptualization, P.C.-F. and L.M.E.; writing-original draft preparation P.C.-F., M.M.E., M.S.-P.; writing - review and editing, J.M.F., M.E.T. and L.M.E.; supervision, J.M.F., M.E.T. and L.M.E. All authors have read and agreed to the published version of the manuscript.

Funding: This research received no external funding.

Conflicts of Interest: The authors declare no conflict of interest.

\section{References}

1. Sir Alexander Fleming-Nobel Lecture: Penicillin. Available online: https://www.nobelprize.org/prizes/ medicine/1945/fleming/lecture/ (accessed on 27 August 2020).

2. ECDC. Surveillance of Antimicrobial Resistance in Europe Annual Report of the European Antimicrobial Resistance Surveillance Network (2018); ECDC: Stockholm, Sweden, 2019.

3. Prestinaci, F.; Pezzotti, P.; Pantosti, A. Antimicrobial resistance: A global multifaceted phenomenon. Pathog. Glob. Health 2015, 109, 309-318. [CrossRef] [PubMed]

4. World Health Organization (WHO). Antibiotic Resistance. Available online: https://www.who.int/newsroom/fact-sheets/detail/antibiotic-resistance (accessed on 28 August 2020).

5. Hernando-Amado, S.; Coque, T.M.; Baquero, F.; Martínez, J.L. Antibiotic Resistance: Moving from Individual Health Norms to Social Norms in One Health and Global Health. Front. Microbiol. 2020, 11, 1914. [CrossRef] [PubMed]

6. Oniciuc, E.A.; Likotrafiti, E.; Alvarez-Molina, A.; Prieto, M.; López, M.; Alvarez-Ordóñez, A. Food processing as a risk factor for antimicrobial resistance spread along the food chain. Curr. Opin. Food Sci. 2019, 30, 21-26. [CrossRef]

7. León-Buitimea, A.; Garza-Cárdenas, C.R.; Garza-Cervantes, J.A.; Lerma-Escalera, J.A.; Morones-Ramírez, J.R. The Demand for New Antibiotics: Antimicrobial Peptides, Nanoparticles, and Combinatorial Therapies as Future Strategies in Antibacterial Agent Design. Front. Microbiol. 2020, 11, 1669. [CrossRef]

8. Al Alsheikh, H.M.; Sultan, I.; Kumar, V.; Rather, I.A.; Al-Sheikh, H.; Jan, A.T.; Haq, Q.M.R. Plant-based phytochemicals as possible alternative to antibiotics in combating bacterial drug resistance. Antibiotics 2020, 9, 480. [CrossRef]

9. Wozniak, T.M.; Barnsbee, L.; Lee, X.J.; Pacella, R.E. Using the best available data to estimate the cost of antimicrobial resistance: A systematic review. Antimicrob. Resist. Infect. Control 2019, 8, 26. [CrossRef] [PubMed]

10. Morel, C.M.; Lindahl, O.; Harbarth, S.; de Kraker, M.E.A.; Edwards, S.; Hollis, A. Industry incentives and antibiotic resistance: An introduction to the antibiotic susceptibility bonus. J. Antibiot. 2020, 73, 421-428. [CrossRef]

11. Carter, D.A.; Blair, S.E.; Cokcetin, N.N.; Bouzo, D.; Brooks, P.; Schothauer, R.; Harry, E.J. Therapeutic Manuka Honey: No Longer So Alternative. Front. Microbiol. 2016, 7, 569. [CrossRef] [PubMed]

12. Henriques, A.F.; Jenkins, R.E.; Burton, N.F.; Cooper, R.A. The intracellular effects of manuka honey on Staphylococcus aureus. Eur. J. Clin. Microbiol. Infect. Dis. 2010, 29, 45-50. [CrossRef]

13. Maddocks, S.E.; Jenkins, R.E. Honey: A sweet solution to the growing problem of antimicrobial resistance? Future Microbiol. 2013, 8, 1419-1429. [CrossRef]

14. Nolan, V.C.; Harrison, J.; Cox, J.A.G. Dissecting the antimicrobial composition of honey. Antibiotics 2019, 8, 251. [CrossRef]

15. Da Silva, P.M.; Gauche, C.; Gonzaga, L.V.; Costa, A.C.O.; Fett, R. Honey: Chemical composition, stability and authenticity. Food Chem. 2016, 196, 309-323. [CrossRef]

16. Combarros-Fuertes, P.; Valencia-Barrera, R.M.; Estevinho, L.M.; Dias, L.G.; Castro, J.M.; Tornadijo, M.E.; Fresno, J.M. Spanish honeys with quality brand: A multivariate approach to physicochemical parameters, microbiological quality and floral origin. J. Apic. Res. 2019, 58, 92-103. [CrossRef]

17. Albaridi, N.A. Antibacterial Potency of Honey. Int. J. Microbiol. 2019, 2019, 4507. [CrossRef] [PubMed] 
18. Zamora, M.C.; Chirife, J. Determination of water activity change due to crystallization in honeys from Argentina. Food Control 2006, 17, 59-64. [CrossRef]

19. Kwakman, P.H.S.; Zaat, S.A.J. Antibacterial components of honey. IUBMB Life 2012, 64, 48-55. [CrossRef]

20. Truchado, P.; López-Gálvez, F.; Gil, M.I.; Tomás-Barberán, F.A.; Allende, A. Quorum sensing inhibitory and antimicrobial activities of honeys and the relationship with individual phenolics. Food Chem. 2009, 115, 1337-1344. [CrossRef]

21. Lee, J.H.; Park, J.H.; Kim, J.A.; Neupane, G.P.; Cho, M.H.; Lee, C.S.; Lee, J. Low concentrations of honey reduce biofilm formation, quorum sensing, and virulence in Escherichia coli O157:H7. Biofouling 2011, 27, 1095-1104. [CrossRef] [PubMed]

22. Proaño, A.; Coello, D.; Villacrés-Granda, I.; Ballesteros, I.; Debut, A.; Vizuete, K.; Brenciani, A.; Álvarez-Suarez,J.M. The osmotic action of sugar combined with hydrogen peroxide and bee-derived antibacterial peptide Defensin-1 is crucial for the antibiofilm activity of eucalyptus honey. LWT 2021, 136, 110379. [CrossRef]

23. Henriques, A.F.; Jenkins, R.E.; Burton, N.F.; Cooper, R.A. The effect of manuka honey on the structure of Pseudomonas aeruginosa. Eur. J. Clin. Microbiol. Infect. Dis. 2011, 30, 167-171. [CrossRef]

24. Jenkins, R.; Burton, N.; Cooper, R. Manuka honey inhibits cell division in methicillin-resistant Staphylococcus aureus. J. Antimicrob. Chemother. 2011, 66, 2536-2542. [CrossRef]

25. Bouzo, D.; Cokcetin, N.N.; Li, L.; Ballerin, G.; Bottomley, A.L.; Lazenby, J.; Whitchurch, C.B.; Paulsen, I.T.; Hassan, K.A.; Harry, E.J. Characterizing the mechanism of action of an ancient antimicrobial, manuka honey, against pseudomonas aeruginosa using modern transcriptomics. mSystems 2020, 5, e00106-20. [CrossRef]

26. Wilkins, A.L.; Lu, Y.; Tan, S.T. Extractives from New Zealand Honeys. 5. Aliphatic Dicarboxylic Acids in New Zealand Rewarewa (Knightea excelsa) Honey. J. Agric. Food Chem. 1995, 43, 3021-3025. [CrossRef]

27. Alvarez-Suarez, J.M. Bee Products_Chemical and Biological Properties; Springer International Publishing: Basel, Switzerland, 2017; ISBN 9783319596891.

28. Karabagias, I.K.; Vavoura, M.V.; Nikolaou, C.; Badeka, A.V.; Kontakos, S.; Kontominas, M.G. Floral authentication of Greek unifloral honeys based on the combination of phenolic compounds, physicochemical parameters and chemometrics. Food Res. Int. 2014, 62, 753-760. [CrossRef]

29. Olaitan, P.B.; Adeleke, O.E.; Ola, I.O. Honey: A reservoir for microorganisms and an inhibitory agent for microbes. Afr. Health Sci. 2007, 7, 159-165. [PubMed]

30. Combarros-Fuertes, P.; Estevinho, L.M.; Dias, L.G.; Castro, J.M.; Tomás-Barberán, F.A.; Tornadijo, M.E.; Fresno-Baro, J.M. Bioactive Components and Antioxidant and Antibacterial Activities of Different Varieties of Honey: A Screening Prior to Clinical Application. J. Agric. Food Chem. 2019, 67, 688-698. [CrossRef]

31. Brudzynski, K. A current perspective on hydrogen peroxide production in honey. A review. Food Chem. 2020, 332, 127229. [CrossRef]

32. Brudzynski, K.; Miotto, D.; Kim, L.; Sjaarda, C.; Maldonado-Alvarez, L.; Fukś, H. Active macromolecules of honey form colloidal particles essential for honey antibacterial activity and hydrogen peroxide production. Sci. Rep. 2017, 7, 7637. [CrossRef]

33. Brudzynski, K.; Abubaker, K.; St-Martin, L.; Castle, A. Re-examining the role of hydrogen peroxide in bacteriostatic and bactericidal activities of honey. Front. Microbiol. 2011, 2, 213. [CrossRef]

34. Brudzynski, K.; Abubaker, K.; Wang, T. Powerful bacterial killing by buckwheat honeys is concentration-dependent, involves complete DNA degradation and requires hydrogen peroxide. Front. Microbiol. 2012, 3, 242. [CrossRef]

35. Poli, J.P.; Guinoiseau, E.; Luciani, A.; Yang, Y.; Battesti, M.J.; Paolini, J.; Costa, J.; Quilichini, Y.; Berti, L.; Lorenzi, V. Key role of hydrogen peroxide in antimicrobial activity of spring, Honeydew maquis and chestnut grove Corsican honeys on Pseudomonas aeruginosa DNA. Lett. Appl. Microbiol. 2018, 66, 427-433. [CrossRef]

36. Sindi, A.; Chawn, M.V.B.; Hernandez, M.E.; Green, K.; Islam, M.K.; Locher, C.; Hammer, K. Anti-biofilm effects and characterisation of the hydrogen peroxide activity of a range of Western Australian honeys compared to Manuka and multifloral honeys. Sci. Rep. 2019, 9, 17666. [CrossRef]

37. Brudzynski, K.; Abubaker, K.; Miotto, D. Unraveling a mechanism of honey antibacterial action: Polyphenol $/ \mathrm{H}_{2} \mathrm{O}_{2}$-induced oxidative effect on bacterial cell growth and on DNA degradation. Food Chem. 2012, 133, 329-336. [CrossRef]

38. Fyfe, L.; Okoro, P.; Paterson, E.; Coyle, S.; McDougall, G.J. Compositional analysis of Scottish honeys with antimicrobial activity against antibiotic-resistant bacteria reveals novel antimicrobial components. LWT-Food Sci. Technol. 2017, 79, 52-59. [CrossRef] 
39. Bucekova, M.; Jardekova, L.; Juricova, V.; Bugarova, V.; Di Marco, G.; Gismondi, A.; Leonardi, D.; Farkasovska, J.; Godocikova, J.; Laho, M.; et al. Antibacterial Activity of Different Blossom Honeys: New Findings. Molecules 2019, 24, 1573. [CrossRef]

40. Sousa, J.M.; de Souza, E.L.; Marques, G.; Meireles, B.; de Magalhães Cordeiro, Â.T.; Gullón, B.; Pintado, M.M.; Magnani, M. Polyphenolic profile and antioxidant and antibacterial activities of monofloral honeys produced by Meliponini in the Brazilian semiarid region. Food Res. Int. 2016, 84, 61-68. [CrossRef]

41. Liu, J.R.; Ye, Y.L.; Lin, T.Y.; Wang, Y.W.; Peng, C.C. Effect of floral sources on the antioxidant, antimicrobial, and anti-inflammatory activities of honeys in Taiwan. Food Chem. 2013, 139, 938-943. [CrossRef] [PubMed]

42. Truchado, P.; Martos, I.; Bortolotti, L.; Sabatini, A.G.; Ferreres, F.; Tomas-Barberan, F.A. Use of Quinoline Alkaloids as Markers of the Floral Origin of Chestnut Honey. J. Agric. Food Chem. 2009, 57, 5680-5686. [CrossRef]

43. Ferreres, F.; Andrade, P.; Tomás-Barberán, F.A. Natural Occurrence of Abscisic Acid in Heather Honey and Floral Nectar. J. Agric. Food Chem. 1996, 44, 2053-2056. [CrossRef]

44. Cushnie, T.P.T.; Lamb, A.J. Recent advances in understanding the antibacterial properties of flavonoids. Int. J. Antimicrob. Agents 2011, 38, 99-107. [CrossRef]

45. Cushnie, T.P.T.; Lamb, A.J. Antimicrobial activity of flavonoids. Int. J. Antimicrob. Agents 2005, 26, $343-356$. [CrossRef] [PubMed]

46. Ahmad, A.; Kaleem, M.; Ahmed, Z.; Shafiq, H. Therapeutic potential of flavonoids and their mechanism of action against microbial and viral infections-A review. Food Res. Int. 2015, 77, 221-235. [CrossRef]

47. Combarros-Fuertes, P.; Estevinho, L.M.; Teixeira-Santos, R.; Rodrigues, A.G.; Pina-Vaz, C.; Fresno, J.M.; Eugenia Tornadijo, M. Antibacterial action mechanisms of honey: Physiological Effects of Avocado, Chestnut, and Polyfloral Honey upon Staphylococcus aureus and Escherichia coli. Molecules 2020, 25, 1252. [CrossRef] [PubMed]

48. Williams, S.; King, J.; Revell, M.; Manley-Harris, M.; Balks, M.; Janusch, F.; Kiefer, M.; Clearwater, M.; Brooks, P.; Dawson, M. Regional, annual, and individual variations in the dihydroxyacetone content of the nectar of Manuka (Leptospermum scoparium) in New Zealand. J. Agric. Food Chem. 2014, 62, 10332-10340. [CrossRef]

49. Adams, C.J.; Manley-Harris, M.; Molan, P.C. The origin of methylglyoxal in New Zealand manuka (Leptospermum scoparium) honey. Carbohydr. Res. 2009, 344, 1050-1053. [CrossRef] [PubMed]

50. Tang, J.S.; Compton, B.J.; Marshall, A.; Anderson, R.; Li, Y.; van der Woude, H.; Hermans, I.F.; Painter, G.F.; Gasser, O. Mānuka honey-derived methylglyoxal enhances microbial sensing by mucosal-associated invariant T cells. Food Funct. 2020, 11, 5782-5787. [CrossRef]

51. Salonen, A.; Virjamo, V.; Tammela, P.; Fauch, L.; Julkunen-Tiitto, R. Screening bioactivity and bioactive constituents of Nordic unifloral honeys. Food Chem. 2017, 237, 214-224. [CrossRef]

52. Arena, E.; Ballistreri, G.; Tomaselli, F.; Fallico, B. Survey of 1,2-Dicarbonyl Compounds in Commercial Honey of Different Floral Origin. J. Food Sci. 2011, 76, C1203-C1210. [CrossRef]

53. Oinaala, D.; Lehesvaara, M.; Lyhs, U.; Tikkanen-Kaukanen, C. Antimicrobial activity of organic honeys against food pathogenic bacterium Clostridium perfringens. Org. Agric. 2015, 5, 153-159. [CrossRef]

54. Karabagias, I.K.; Maia, M.; Karabagias, V.K.; Gatzias, I.; Badeka, A.V. Quality and origin characterisation of Portuguese, Greek, Oceanian, and Asian honey, based on poly-parametric analysis hand in hand with dimension reduction and classification techniques. Eur. Food Res. Technol. 2020, 246, 987-1006. [CrossRef]

55. Rabie, E.; Serem, J.C.; Oberholzer, H.M.; Gaspar, A.R.M.; Bester, M.J. How methylglyoxal kills bacteria: An ultrastructural study. Ultrastruct. Pathol. 2016, 40, 107-111. [CrossRef]

56. Casteels-Josson, K.; Zhang, W.; Capaci, T.; Casteels, P.; Tempst, P. Acute transcriptional response of the honeybee peptide-antibiotics gene repertoire and required post-translational conversion of the precursor structures. J. Biol. Chem. 1996, 269, 28569-28575.

57. Ilyasov, R.A.; Gaifullina, L.R.; Saltykova, E.S.; Poskryakov, A.V.; Nikolenko, A.G. Review of the expression of antimicrobial peptide defensin in honey bees Apis Mellifera L. J. Apic. Sci. 2012, 56, 115-124. [CrossRef]

58. Erban, T.; Shcherbachenko, E.; Talacko, P.; Harant, K. The Unique Protein Composition of Honey Revealed by Comprehensive Proteomic Analysis: Allergens, Venom-like Proteins, Antibacterial Properties, Royal Jelly Proteins, Serine Proteases, and Their Inhibitors. J. Nat. Prod. 2019, 82, 1217-1226. [CrossRef]

59. Kwakman, P.H.S.; Velde, A.A.T.; Boer, L.; Speijer, D.; Christina Vandenbroucke-Grauls, M.J.; Zaat, S.A.J. How honey kills bacteria. FASEB J. 2010, 24, 2576-2582. [CrossRef] 
60. Kwakman, P.H.S.; De Boer, L.; Ruyter-Spira, C.P.; Creemers-Molenaar, T.; Helsper, J.P.F.G.; Vandenbroucke-Grauls, C.M.J.E.; Zaat, S.A.J.; Te Velde, A.A. Medical-grade honey enriched with antimicrobial peptides has enhanced activity against antibiotic-resistant pathogens. Eur. J. Clin. Microbiol. Infect. Dis. 2011, 30, 251-257. [CrossRef]

61. Kwakman, P.H.S.; Velde, A.A.T.; de Boer, L.; Vandenbroucke-Grauls, C.M.J.E.; Zaat, S.A.J. Two Major Medicinal Honeys Have Different Mechanisms of Bactericidal Activity. PLoS ONE 2011, 6, e17709. [CrossRef]

62. Valachová, I.; Bučeková, M.; Majtán, J. Quantification of bee-derived peptide. Czech J. Food Sci. 2016, 34, 233-243.

63. Liu, M.; Lu, J.; Müller, P.; Turnbull, L.; Burke, C.M.; Schlothauer, R.C.; Carter, D.A.; Whitchurch, C.B.; Harry, E.J. Antibiotic-specific differences in the response of Staphylococcus aureus to treatment with antimicrobials combined with manuka honey. Front. Microbiol. 2015, 5, 779. [CrossRef]

64. Combarros-Fuertes, P.; Estevinho, L.M.; Teixeira-Santos, R.; Rodrigues, A.G.; Pina-Vaz, C.; Fresno, J.M.; Tornadijo, M.E. Evaluation of Physiological Effects Induced by Manuka Honey Upon Staphylococcus aureus and Escherichia coli. Microorganisms 2019, 7, 258. [CrossRef]

65. Roberts, A.E.L.; Maddocks, S.E.; Cooper, R.A. Manuka honey is bactericidal against Pseudomonas aeruginosa and results in differential expression of oprF and algD. Microbiology 2012, 158, 3005-3013. [CrossRef]

66. Lu, J.; Carter, D.A.; Turnbull, L.; Rosendale, D.; Hedderley, D.; Stephens, J.; Gannabathula, S.; Steinhorn, G.; Schlothauer, R.C.; Whitchurch, C.B.; et al. The Effect of New Zealand Kanuka, Manuka and Clover Honeys on Bacterial Growth Dynamics and Cellular Morphology Varies According to the Species. PLoS ONE 2013, mboxemph8, e55898. [CrossRef]

67. Brudzynski, K.; Sjaarda, C. Antibacterial compounds of canadian honeys target bacterial cell wall inducing phenotype changes, growth inhibition and cell lysis that resemble action of $\beta$-lactam antibiotics. PLoS ONE 2014, 9, e106967. [CrossRef]

68. Wasfi, R.; Elkhatib, W.F.; Khairalla, A.S. Effects of selected egyptian honeys on the cellular ultrastructure and the gene expression profile of Escherichia coli. PLoS ONE 2016, 11, e0150984. [CrossRef]

69. Anand, S.; Deighton, M.; Livanos, G.; Morrison, P.D.; Pang, E.C.K.; Mantri, N. Antimicrobial activity of Agastache honey and characterization of its bioactive compounds in comparison with important commercial honeys. Front. Microbiol. 2019, 10, 263. [CrossRef]

70. Roberts, A.E.L.; Maddocks, S.E.; Cooper, R.A. Manuka honey reduces the motility of Pseudomonas aeruginosa by suppression of flagella-associated genes. J. Antimicrob. Chemother. 2015, 70, 716-725. [CrossRef]

71. Sträuber, H.; Müller, S. Viability states of bacteria-Specific mechanisms of selected probes. Cytom. Part A 2010, 77, 623-634. [CrossRef]

72. Strahl, H.; Hamoen, L.W. Membrane potential is important for bacterial cell division. Proc. Natl. Acad. Sci. USA 2010, 107, 12281-12286. [CrossRef]

73. Jenkins, R.; Burton, N.; Cooper, R. Proteomic and genomic analysis of methicillin-resistant Staphylococcus aureus (MRSA) exposed to manuka honey in vitro demonstrated down-regulation of virulence markers. J. Antimicrob. Chemother. 2014, 69, 603-615. [CrossRef]

74. Blair, S.E.; Cokcetin, N.N.; Harry, E.J.; Carter, D.A. The unusual antibacterial activity of medical-grade Leptospermum honey: Antibacterial spectrum, resistance and transcriptome analysis. Eur. J. Clin. Microbiol. Infect. Dis. 2009, 28, 1199-1208. [CrossRef]

75. Ankley, L.M.; Monteiro, M.P.; Camp, K.M.; O'Quinn, R.; Castillo, A.R. Manuka honey chelates iron and impacts iron regulation in key bacterial pathogens. J. Appl. Microbiol. 2020, 128, 1015-1024. [CrossRef]

76. Kronda, J.M.; Cooper, R.A.; Maddocks, S.E. Manuka honey inhibits siderophore production in Pseudomonas aeruginosa. J. Appl. Microbiol. 2013, 115, 86-90. [CrossRef]

77. Lu, W.-J.; Lin, H.-J.; Hsu, P.-H.; Lin, H.-T.V. Determination of Drug Efflux Pump Efficiency in Drug-Resistant Bacteria Using MALDI-TOF MS. Antibiotics 2020, 9, 639. [CrossRef]

78. Muniz, D.F.; dos Santos Barbosa, C.R.; de Menezes, I.R.A.; de Sousa, E.O.; Pereira, R.L.S.; Júnior, J.T.C.; Pereira, P.S.; de Matos, Y.M.L.S.; da Costa, R.H.S.; de Morais Oliveira-Tintino, C.D.; et al. In vitro and in silico inhibitory effects of synthetic and natural eugenol derivatives against the NorA efflux pump in Staphylococcus aureus. Food Chem. 2021, 337, 127776. [CrossRef]

79. Jenkins, R.; Cooper, R. Improving Antibiotic Activity against Wound Pathogens with Manuka Honey In Vitro. PLoS ONE 2012, 7, e45600. [CrossRef] [PubMed] 
80. Wang, R.; Starkey, M.; Hazan, R.; Rahme, L.G. Honey's ability to counter bacterial infections arises from both bactericidal compounds and QS inhibition. Front. Microbiol. 2012, 3, 144. [CrossRef]

81. Jadaun, V.; Prateeksha, P.; Singh, B.R.; Paliya, B.S.; Upreti, D.K.; Rao, C.V.; Rawat, A.K.S.; Singh, B.N. Honey enhances the anti-quorum sensing activity and anti-biofilm potential of curcumin. RSC Adv. 2015, 5, 71060-71070. [CrossRef]

82. Fernandes, L.; Oliveira, A.; Henriques, M.; Rodrigues, M.E. Honey as a strategy to fight candida tropicalis in mixed-biofilms with pseudomonas aeruginosa. Antibiotics 2020, 9, 43. [CrossRef] [PubMed]

83. Prateeksha, S.B.; Shoeb, M.; Sharma, S.; Naqvi, A.H.; Gupta, V.K.; Singh, B.N. Scaffold of Selenium Nanovectors and Honey Phytochemicals for Inhibition of Pseudomonas aeruginosa Quorum Sensing and Biofilm Formation. Front. Cell. Infect. Microbiol. 2017, 7, 93. [CrossRef] [PubMed]

84. Cooper, R.; Jenkins, L.; Hooper, S. Inhibition of biofilms of Pseudomonas aeruginosa by Medihoney in vitro. J. Wound Care 2014, 23, 93-104. [CrossRef]

85. Maddocks, S.E.; Lopez, M.S.; Rowlands, R.S.; Cooper, R.A. Manuka honey inhibits the development of Streptococcus pyogenes biofilms and causes reduced expression of two fibronectin binding proteins. Microbiology 2012, 158, 781-790. [CrossRef]

86. Merckoll, P.; Jonassen, T.Ø.; Vad, M.E.; Jeansson, S.L.; Melby, K.K. Bacteria, biofilm and honey: A study of the effects of honey on "planktonic" and biofilm-embedded chronic wound bacteria. Scand. J. Infect. Dis. 2009, 41, 341-347. [CrossRef]

87. Lu, J.; Cokcetin, N.N.; Burke, C.M.; Turnbull, L.; Liu, M.; Carter, D.A.; Whitchurch, C.B.; Harry, E.J. Honey can inhibit and eliminate biofilms produced by Pseudomonas aeruginosa. Sci. Rep. 2019, 9, 1-13. [CrossRef]

88. Kot, B.; Sytykiewicz, H.; Sprawka, I.; Witeska, M. Effect of manuka honey on biofilm-associated genes expression during methicillin-resistant Staphylococcus aureus biofilm formation. Sci. Rep. 2020, 10, 13552. [CrossRef] [PubMed]

89. Jenkins, R.; Burton, N.; Cooper, R. Effect of manuka honey on the expression of universal stress protein A in meticillin-resistant Staphylococcus aureus. Int. J. Antimicrob. Agents 2011, 37, 373-376. [CrossRef]

90. Packer, J.M.; Irish, J.; Herbert, B.R.; Hill, C.; Padula, M.; Blair, S.E.; Carter, D.A.; Harry, E.J. Specific non-peroxide antibacterial effect of manuka honey on the Staphylococcus aureus proteome. Int. J. Antimicrob. Agents 2012, 40, 43-50. [CrossRef] [PubMed]

91. Jenkins, R.; Wootton, M.; Howe, R.; Cooper, R. Susceptibility to manuka honey of Staphylococcus aureus with varying sensitivities to vancomycin. Int. J. Antimicrob. Agents 2012, 40, 88-89. [CrossRef]

92. Cooper, R.; Jenkins, R. Are there feasible prospects for manuka honey as an alternative to conventional antimicrobials? Expert Rev. Anti. Infect. Ther. 2012, 10, 623-625. [CrossRef]

93. Natarajan, S.; Williamson, D.; Grey, J.; Harding, K.G.; Cooper, R.A. Healing of an MRSA-colonized, hydroxyurea-induced leg ulcer with honey. J. Dermatol. Treat. 2001, 12, 33-36. [CrossRef]

94. Girma, A.; Seo, W.; SheI, R.C. Antibacterial activity of varying UMF-graded Manuka honeys. PLoS ONE 2019, 14, e0224495. [CrossRef]

95. Jenkins, R.E.; Cooper, R. Synergy between oxacillin and manuka honey sensitizes methicillin-resistant Staphylococcus aureus to oxacillin. J. Antimicrob. Chemother. 2012, 67, 1405-1407. [CrossRef]

96. George, N.M.; Cutting, K.F. Antibacterial Honey: In-vitro Activity Against Clinical Isolates of MRSA, VRE, and Other Multiresistant Gram-negative Organisms | Wounds Research. Wounds 2007, 19, 231-236.

97. Mokhtar, J.A.; McBain, A.J.; Ledder, R.G.; Binsuwaidan, R.; Rimmer, V.; Humphreys, G.J. Exposure to a Manuka Honey Wound Gel Is Associated With Changes in Bacterial Virulence and Antimicrobial Susceptibility. Front. Microbiol. 2020, 11, 2036. [CrossRef] [PubMed]

98. Müller, P.; Alber, D.G.; Turnbull, L.; Schlothauer, R.C.; Carter, D.A.; Whitchurch, C.B.; Harry, E.J. Synergism between Medihoney and Rifampicin against Methicillin-ResistantStaphylococcus aureus (MRSA). PLoS ONE 2013, 8, e57679.

99. Cremers, N.; Belas, A.; Santos Costa, S.; Couto, I.; de Rooster, H.; Pomba, C. In vitro antimicrobial efficacy of two medical grade honey formulations against common high-risk meticillin-resistant staphylococci and Pseudomonas spp. pathogens. Vet. Dermatol. 2020, 31, 90. [CrossRef]

100. Cooper, R.A.; Molan, P.C.; Harding, K.G. The sensitivity to honey of Gram-positive cocci of clinical significance isolated from wounds. J. Appl. Microbiol. 2002, 93, 857-863. [CrossRef]

101. Gethin, G.; Cowman, S. Bacteriological changes in sloughy venous leg ulcers treated with manuka honey or hydrogel: An RCT. J. Wound Care 2008, 17, 241-247. [CrossRef] [PubMed] 
102. Idris, A.R.; Afegbua, S.L. Single and joint antibacterial activity of aqueous garlic extract and Manuka honey on extended-spectrum beta-lactamase-producing Escherichia coli. Trans. R. Soc. Trop. Med. Hyg. 2017, 111, 472-478. [CrossRef]

103. Shah Pratibha, J.; Williamson Manita, T. Antibacterial activity of honey against ESBL producing Klebsiella pneumoniae from burn wound infections. Int. J. Curr. Pharm. Res. 2015, 7, 32-36.

104. Qamar, M.U.; Saleem, S.; Toleman, M.A.; Saqalein, M.; Waseem, M.; Nisar, M.A.; Khurshid, M.; Taj, Z.; Jahan, S. In vitro and in vivo activity of Manuka honey against NDM-1-producing Klebsiella pneumoniae ST11. Future Microbiol. 2018, 13, 13-26. [CrossRef]

105. Hillitt, K.L.; Jenkins, R.E.; Spiller, O.B.; Beeton, M.L. Antimicrobial activity of Manuka honey against antibiotic-resistant strains of the cell wall-free bacteria Ureaplasma parvum and Ureaplasma urealyticum. Lett. Appl. Microbiol. 2017, 64, 198-202. [CrossRef]

106. Johnson, D.W.; Van Eps, C.; Mudge, D.W.; Wiggins, K.J.; Armstrong, K.; Hawley, C.M.; Campbell, S.B.; Isbel, N.M.; Nimmo, G.R.; Gibbs, H. Randomized, controlled trial of topical exit-site application of honey (Medihoney) versus mupirocin for the prevention of catheter-associated infections in hemodialysis patients. J. Am. Soc. Nephrol. 2005, 16, 1456-1462. [CrossRef] [PubMed]

107. Kwakman, P.H.S.; Van Den Akker, J.P.C.; Güçlü, A.; Aslami, H.; Binnekade, J.M.; De Boer, L.; Boszhard, L.; Paulus, F.; Middelhoek, P.; Te Velde, A.A.; et al. Medical-grade honey kills antibiotic-resistant bacteria in vitro and eradicates skin colonization. Clin. Infect. Dis. 2008, 46, 1677-1682. [CrossRef]

108. Nair, H.K.R.; Tatavilis, N.; Pospíšilová, I.; Kučerová, J.; Cremers, N.A.J. Medical-grade honey kills antibiotic-resistant bacteria and prevents amputation in diabetics with infected ulcers: A prospective case series. Antibiotics 2020, 9, 529. [CrossRef]

109. Malika, N.O.A.M.A.N.; Mohamed, F.; Chakib, E.A. Antimicrobial Activities of Natural Honey from Aromatic and Medicinal Plants on Antibio-resistant Strains of Bacteria. Int. J. Agric. Biol. 2004, 6, 289-293.

110. Sherlock, O.; Dolan, A.; Athman, R.; Power, A.; Gethin, G.; Cowman, S.; Humphreys, H. Comparison of the antimicrobial activity of Ulmo honey from Chile and Manuka honey against methicillin-resistant Staphylococcus aureus, Escherichia coli and Pseudomonas aeruginosa. BMC Complement. Altern. Med. 2010, 10, 47. [CrossRef]

111. Brudzynski, K.; Lannigan, R. Mechanism of Honey Bacteriostatic Action against MRSA and VRE Involves Hydroxyl Radicals Generated from Honey's Hydrogen Peroxide. Front. Microbiol. 2012, 3, 36. [CrossRef]

112. Hussain, M.B.; Hannan, A.; Absar, M.; Butt, N.S. In-vitro susceptibility of methicillin-resistant Stayphylococcus aureus to honey. Complement. Ther. Clin. Pract. 2017, 27, 57-60. [CrossRef]

113. Bazzi, A.M.; Rabaan, A.A.; Al-Tawfiq, J.A.; Shannak, B.M. Comparison of Effectiveness of Germania Honey Compared to Manuka Honey in Methicillin-Resistant Staphylococcus aureus (MRSA) Killing. Open Microbiol. J. 2019, 13, 21-27. [CrossRef]

114. Gobin, I.; Crnković, G.; Magdalenić, M.; Begić, G.; Babić, A.; Lušić, D.; Vučković, D. Antibacterial potential of Croatian honey against antibiotic resistant pathogenic bacteria. Med. Glas. 2018, 15, 139-144.

115. Cooper, R.A.; Jenkins, L.; Henriques, A.F.M.; Duggan, R.S.; Burton, N.F. Absence of bacterial resistance to medical-grade manuka honey. Eur. J. Clin. Microbiol. Infect. Dis. 2010, 29, 1237-1241. [CrossRef]

116. Camplin, A.L.; Maddocks, S.E. Manuka honey treatment of biofilms of Pseudomonas aeruginosa results in the emergence of isolates with increased honey resistance. Ann. Clin. Microbiol. Antimicrob. 2014, 13, 19. [CrossRef]

117. Campeau, M.E.M.; Patel, R. Antibiofilm Activity of Manuka Honey in Combination with Antibiotics. Int. J. Bacteriol. 2014, 2014, 1-7. [CrossRef]

118. Hayes, G.; Wright, N.; Gardner, S.L.; Telzrow, C.L.; Wommack, A.J.; Vigueira, P.A. Manuka honey and methylglyoxal increase the sensitivity of Staphylococcus aureus to linezolid. Lett. Appl. Microbiol. 2018, 66, 491-495. [CrossRef]

119. Liu, M.Y.; Cokcetin, N.N.; Lu, J.; Turnbull, L.; Carter, D.A.; Whitchurch, C.B.; Harry, E.J. Rifampicin-Manuka Honey Combinations Are Superior to Other Antibiotic-Manuka Honey Combinations in Eradicating Staphylococcus aureus Biofilms. Front. Microbiol. 2018, 8, 2653. [CrossRef]

120. Al-Waili, N.S.; Salom, K.; Butler, G.; Al Ghamdi, A.A. Honey and microbial infections: A review supporting the use of honey for microbial control. J. Med. Food 2011, 14, 1079-1096. [CrossRef] 
121. Hossen, M.S.; Ali, M.Y.; Jahurul, M.H.A.; Abdel-Daim, M.M.; Gan, S.H.; Khalil, M.I. Beneficial roles of honey polyphenols against some human degenerative diseases: A review. Pharmacol. Rep. 2017, 69, 1194-1205. [CrossRef]

122. Gunduz, A.; Turedi, S.; Russell, R.M.; Ayaz, F.A. Clinical review of grayanotoxin/mad honey poisoning past and present. Clin. Toxicol. 2008, 46, 437-442. [CrossRef]

123. Gunduz, A.; Turedi, S.; Oksuz, H. The honey, the poison, the weapon. Wilderness Environ. Med. 2011, 22, 182-184. [CrossRef]

124. Krishnakumar, G.S.; Mahendiran, B.; Gopalakrishnan, S.; Muthusamy, S.; Malarkodi Elangovan, S. Honey based treatment strategies for infected wounds and burns: A systematic review of recent pre-clinical research. Wound Med. 2020, 30, 100188. [CrossRef]

125. Simon, A.; Traynor, K.; Santos, K.; Blaser, G.; Bode, U.; Molan, P. Medical honey for wound care-still the 'latest resort'? Evid. Based Complement. Altern. Med. 2009, 6, 165-173. [CrossRef]

126. Roberts, A.E.L.; Brown, H.L.; Jenkins, R. On the antibacterial effects of manuka honey: Mechanistic insights. Res. Rep. Biol. 2015, 6, 215-224.

Publisher's Note: MDPI stays neutral with regard to jurisdictional claims in published maps and institutional affiliations.

(C) 2020 by the authors. Licensee MDPI, Basel, Switzerland. This article is an open access article distributed under the terms and conditions of the Creative Commons Attribution (CC BY) license (http://creativecommons.org/licenses/by/4.0/). 